\title{
Evaluation of the effects of electrical power outages on small and medium scale enterprises (SMEs)
}

Frederick I. Olajide * and A. O. Ibe

Department of Electrical/Electronic Engineering, Faculty of Engineering, University of Port Harcourt, Rivers State, Nigeria.

World Journal of Advanced Engineering Technology and Sciences, 2021, 03(02), 065-073

Publication history: Received on 28September 2021; revised on 05 November 2021; accepted on 07 November 2021

Article DOI: https://doi.org/10.30574/wjaets.2021.3.2.0073

\begin{abstract}
This study evaluated the effects of electrical power outages on Small and Medium Scale Enterprises (SMEs). The study was guided by two specific objectives of determining the cost of alternative sources of power supply and its impact on the profitability of businesses of selected SMEs in Elelenwo community in Obio/Akpor Local Government of Rivers State and to suggest possible ways of reducing the power outages in Elelenwo Community. The costs of power supply using private power generation and that of public power generation from Port Harcourt Electricity Distribution (PHED) were collected from selected SMEs in the study area. Findings established the fact that electrical power outages have significant negative effects on the businesses of small and medium scale enterprises (SMEs) which in turns affect their profitability and sustainability. This was established by finding the correlations of the costs of running businesses with private power generation and that of using public power generation for selected SMEs and the results yielded negative correlation coefficients. The study also suggested possible ways of reducing the power outages.
\end{abstract}

Keywords: Power Outage; Enterprises; Electricity; Generating set; Correlation

\section{Introduction}

Electricity is unarguably, an important component of any production process. Therefore when its supply is limited, it has the potential to directly and/or indirectly affect the economic activities of firms. As a result of this, [1] explained that there is need to measure the output loss associated with electricity outages.

In achieving this, according to [2] an analytical frame work known as production function is used. In this analysis, electricity contributes directly to firms' output as a separate input and indirectly as a determinant of the extent to which other direct input such as capital equipment is used.

In the alternative, an approach in which a survey is carried out can be employed. This subjective method is based on self assessment by asking firms to quantify the loss they incur as a result of electrical power outages. For this approach, there is a great assumption that firms will provide relatively accurate valuation of the costs of frequent replacement or repairs of damaged machinery or equipment or to quantify the lost output due to idled inputs. Therefore, to evaluate the costs of power outages, the simple approach is to sum up all the cost amounts provided in the survey. However, there are many setbacks that can beset the outcome, as there is tendency for many firms to overestimate the incurred costs, and thereby overemphasize the impediment that electrical power outages constitute to their business activities [1]

Undoubtedly, manufacturing sector is one of the important drivers of economic development in any economy today. According to [3] manufacturing sector as an important tool for economic development, affords a country the

${ }^{*}$ Corresponding author: Frederick I. Olajide

Department of Electrical/Electronic Engineering, Faculty of Engineering, University of Port Harcourt, Rivers State, Nigeria. 
opportunity to fully deploy and utilize its endowed potentials and thereby reduce its dependency on importation of finished goods and raw materials for its economic growth, development and sustainability. In this regard successive governments in Nigeria have, through budgetary allocations, policies and pronouncements, put effort to increase and sustain the productivity of manufacturing sectors in the economy. With the decline in the oil revenue which is the major earner for the country over the years, the Nigeria government has been putting effort to diversify the economy and attention is shifting towards stimulating the development of the manufacturing sector. In the work of [4] it was admitted that electricity supply, which is principally used for driving machines to produce several items, is a key factor that will improve the productivity of the manufacturing sector which will in turn contribute to the development of the economy.

Despite many attempts by successive governments to improve the power sector of the country by committing a very large amount of money into it, the electric power situation in Nigeria is deteriorating by the day. The so-called privatization of the power sector, has not translated into improved power supply in the country. The persistence of incessant power outages in Nigeria has become worrisome and this is a great challenge to manufacturing sector as well as business enterprises in Nigeria. It is not every manufacturing firm that can profitably run on private power generating set, bearing in mind the competitive nature of the country's business environment and the high costs of fuel and maintenance. This alternative power source supposed to be a backup for smooth and uninterrupted business operations but because of the unreliable power situation in the country, it has become the main source of electric power.

Small and medium scale enterprises (SMEs) sector is an important part of Nigeria economy. It contributes to the creation of jobs and wealth in the economic system of the country. The Small and Medium Scale Enterprises (SMEs) cut across every sector of the economy including manufacturing, Agriculture, services and so on and has significantly contributed to the economic sustainability of the country [5]). In the research carried out by [6], SMEs are said to be the life wire of most economies. They represent $90 \%$ of enterprises and account for $50-60 \%$ of employments as they support the economic growth in developing countries such as Nigeria. In Nigeria, according to the minister of state for industry, trade and investment, Ambassador Mariam Katagum, SMEs employ more than 80\% of the total work force and contribute about half of the Gross Domestic Product (GDP) of the country [7]. India has more than 30 million SME businesses which contribute about 20 percent to their GDP and employ more than 60 million people [8]. SMEs make use of a mixture of novelty and ability to improvise and meet the needs of the local consumers. It is worthwhile to agree that SMEs are contributing immensely to the growth and development of the economy of the nation especially in the developing economies as well as the developed ones.

In the work of [9], it was revealed that though, availability of credit facility is generally believed to be the greatest reason many small and medium scale enterprises fail but recent studies have revealed that many of the failures experienced by most small and medium scale enterprises in Nigeria are traceable to limited supply of electricity. In order to sustain their businesses, most small and medium scale business owners in the country have resulted to the use of alternative electric power supply in spite of the low capital available to them. This situation has greatly increased the production cost. It therefore implies that sufficient electric power supply is greatly needed to run cost effective small and medium scale businesses. Based on the above, it is pertinent to carry out the evaluation of the effects of electrical power outages on small and medium scale enterprises in Elelenwo community of Obio/Akpor Local Government in Rivers State.

\section{Aim and objectives of the study}

The aim of this study is to evaluate the effects of electrical power outages on small and medium scale enterprises (SMEs) in Nigeria. The specific objectives are:

- To determine the cost of alternative sources of power supply and its impact on the Profitability of businesses of selected SMEs in Elelenwo community.

- $\quad$ To suggest possible ways of reducing the power outages in Elelenwo community

\section{Material and methods}

\subsection{Area of Study}

This study focused on the evaluation of the effects of electrical power outages on small and medium scale enterprises in Nigeria and specifically covered some small and medium scale enterprises in Elelenwo community of Obio/Akpor local government area in Rivers state, that their businesses have great dependence on electricity supply. This work examined the commercial power consumption connected to the electricity network of Port Harcourt Electricity Distribution Company of Nigeria (PHED) in Elelenwo Community of Port Harcourt. It carried out the analysis of the cost 
implication of power outages, using the spearman's correlation factor and the frequency of distribution of power outages by a statistical model.

\subsection{Collection of Applicable Data}

The costs of power for using electric power from PHED and that of private generating sets for twenty-four (24) months were obtained from selected SMEs operators within the Elelenwo community. The tables below show the data collected.

Table 1 Cost Data for SME 1 (De-Vine Hotels, 40, Girls School Road Elelenwo, Port Harcourt)

\begin{tabular}{|c|c|c|}
\hline S/N & $\begin{array}{c}\text { Cost of power Supply from PHED } \\
\text { (x 1000 Naira) } \\
\mathbf{X}\end{array}$ & $\begin{array}{c}\text { Total cost of power supply using } \\
\text { private power generating set } \\
\text { (x 1000 Naira) } \\
\mathbf{Y}\end{array}$ \\
\hline 1 & 64 & 434.5 \\
\hline 2 & 40 & 180 \\
\hline 3 & 45 & 250 \\
\hline 4 & 55 & 215 \\
\hline 5 & 50 & 190 \\
\hline 6 & 65 & 160 \\
\hline 7 & 50 & 245 \\
\hline 8 & 40 & 350 \\
\hline 9 & 10 & 445 \\
\hline 10 & 60 & 296 \\
\hline 11 & 55 & 310 \\
\hline 12 & 40 & 445 \\
\hline 13 & 50 & 240 \\
\hline 14 & 60 & 195 \\
\hline 15 & 65 & 140 \\
\hline 16 & 40 & 245 \\
\hline 17 & 50 & 290 \\
\hline 18 & 45 & 265 \\
\hline 19 & 65 & 190 \\
\hline 20 & 65 & 145 \\
\hline 21 & 10 & 450 \\
\hline 22 & 5 & 495 \\
\hline 23 & 40 & 340 \\
\hline 24 & 50 & 295 \\
\hline & & \\
\hline & 5 & \\
\hline & & \\
\hline
\end{tabular}

Table 2 Cost Data for SME 2 (Zion Technology \& Innovation Centre, 69, Old Refinery Road, Elelenwo, Port Harcourt)

\begin{tabular}{|c|c|c|}
\hline S/N & $\begin{array}{c}\text { Cost of power Supply from PHED } \\
\text { (x 1000 Naira) } \\
\mathbf{X}\end{array}$ & $\begin{array}{c}\text { Total cost of power supply using } \\
\text { private power generating set } \\
\text { (x 1000 Naira) } \\
\mathbf{Y}\end{array}$ \\
\hline 1 & 7 & 40 \\
\hline 2 & 8 & 34 \\
\hline 3 & 7.5 & 37 \\
\hline 4 & 8 & 34 \\
\hline 5 & 7 & 40 \\
\hline 6 & 7.5 & 37 \\
\hline 7 & 8 & 35 \\
\hline 8 & 7.5 & 36 \\
\hline
\end{tabular}




\begin{tabular}{|c|c|c|}
\hline 9 & 7 & 39.5 \\
\hline 10 & 8.5 & 37 \\
\hline 11 & 8 & 36.5 \\
\hline 12 & 7 & 37.5 \\
\hline 13 & 7.5 & 35.5 \\
\hline 14 & 8 & 39 \\
\hline 15 & 7 & 40 \\
\hline 16 & 8 & 36 \\
\hline 17 & 7.5 & 37 \\
\hline 18 & 8.5 & 38 \\
\hline 19 & 7 & 35 \\
\hline 20 & 7.5 & 38.5 \\
\hline 21 & 7 & 40 \\
\hline 22 & 5 & 45 \\
\hline 23 & 10 & 31 \\
\hline 24 & 9 & 35 \\
\hline
\end{tabular}

Table 3 Cost Data for SME 3 (ID Best Barbing Salon, 31, Girls School Road Elelenwo, Port Harcourt)

\begin{tabular}{|c|c|c|}
\hline $\mathrm{S} / \mathrm{N}$ & $\begin{array}{l}\text { Cost of power Supply from PHED } \\
\text { (x } 1000 \text { Naira) } \\
\text { X }\end{array}$ & $\begin{array}{c}\text { Total cost of power supply using } \\
\text { private power generating set } \\
\text { (x 1000 Naira) Y }\end{array}$ \\
\hline 1 & 3.5 & 35 \\
\hline 2 & 4 & 31 \\
\hline 3 & 4.5 & 29 \\
\hline 4 & 4 & 33 \\
\hline 5 & 3.5 & 35 \\
\hline 6 & 3.8 & 29.5 \\
\hline 7 & 4 & 31 \\
\hline 8 & 4.5 & 35 \\
\hline 9 & 4 & 33 \\
\hline 10 & 3.5 & 34 \\
\hline 11 & 4.5 & 29.5 \\
\hline 12 & 4 & 33 \\
\hline 13 & 3.8 & 34 \\
\hline 14 & 4 & 32 \\
\hline 15 & 4.5 & 29.5 \\
\hline 16 & 4 & 33 \\
\hline 17 & 3.5 & 35 \\
\hline 18 & 4.5 & 31 \\
\hline 19 & 4 & 32 \\
\hline 20 & 4 & 32 \\
\hline 21 & 4 & 34.5 \\
\hline 22 & 1.5 & 48 \\
\hline 23 & 3.5 & 32 \\
\hline 24 & 4.5 & 34 \\
\hline
\end{tabular}


Table 4 Cost Data for SME 4 (DOMIT Electricals, 34, Girls School Road Elelenwo, Port Harcourt)

\begin{tabular}{|c|c|c|}
\hline $\mathrm{S} / \mathrm{N}$ & $\begin{array}{c}\text { Cost of power Supply from PHED } \\
\text { (x 1000 Naira) } \\
\text { X }\end{array}$ & $\begin{array}{c}\text { Total cost of power supply using } \\
\text { private power generating set } \\
\text { (x 1000 Naira) } \\
\text { Y } \\
\end{array}$ \\
\hline 1 & 4 & 10 \\
\hline 2 & 3 & 6.5 \\
\hline 3 & 3.5 & 6 \\
\hline 4 & 4.5 & 11.5 \\
\hline 5 & 2.5 & 6.5 \\
\hline 6 & 3.5 & 6 \\
\hline 7 & 4.8 & 10 \\
\hline 8 & 4 & 7 \\
\hline 9 & 3 & 10.5 \\
\hline 10 & 3.5 & 6.5 \\
\hline 11 & 4 & 5.5 \\
\hline 12 & 3.5 & 8 \\
\hline 13 & 3.5 & 7.5 \\
\hline 14 & 4.5 & 6.5 \\
\hline 15 & 3 & 8 \\
\hline 16 & 4 & 10.5 \\
\hline 17 & 2.5 & 9.5 \\
\hline 18 & 2.5 & 8.5 \\
\hline 19 & 3 & 7.5 \\
\hline 20 & 3 & 11.5 \\
\hline 21 & 2.5 & 10 \\
\hline 22 & 1 & 12 \\
\hline 23 & 4.5 & 6 \\
\hline 24 & 4 & 7.5 \\
\hline
\end{tabular}

Table 5 Cost Data for SME 5 (REMZ Laundry Services, 53, Old Refinery Road, Elelenwo, Port Harcourt)

\begin{tabular}{|c|c|c|}
\hline S/N & $\begin{array}{c}\text { Cost of power Supply from PHED } \\
\text { (x 1000 Naira) } \\
\mathbf{X}\end{array}$ & $\begin{array}{c}\text { Total cost of power supply using } \\
\text { private power generating set } \\
\text { (x 1000 Naira) } \\
\mathbf{Y}\end{array}$ \\
\hline 1 & 7.5 & 14 \\
\hline 2 & 8 & 11 \\
\hline 3 & 7 & 13.5 \\
\hline 4 & 8 & 12 \\
\hline 5 & 7.5 & 13 \\
\hline 6 & 7 & 13 \\
\hline 7 & 8 & 11.5 \\
\hline 8 & 7.5 & 14.2 \\
\hline 9 & 8 & 14 \\
\hline
\end{tabular}




\begin{tabular}{|c|c|c|}
\hline 10 & 9 & 13.5 \\
\hline 11 & 7 & 13 \\
\hline 12 & 7.5 & 12.5 \\
\hline 13 & 8 & 13 \\
\hline 14 & 7 & 12.5 \\
\hline 15 & 8 & 13 \\
\hline 16 & 8.5 & 13.5 \\
\hline 17 & 7.5 & 14.2 \\
\hline 18 & 9 & 12.5 \\
\hline 19 & 8 & 13.5 \\
\hline 20 & 8.5 & 13 \\
\hline 21 & 5 & 17 \\
\hline 22 & 2 & 21 \\
\hline 23 & 7 & 13.5 \\
\hline 24 & 7.5 & 12 \\
\hline
\end{tabular}

\subsection{Data analysis}

To determine the effect of running a private power generating set during the power outages of PHED utility power, the Pearson product moment correlation was employed to calculate the correlation between the cost of power from private generating set and the cost of power from the PHED utility power for each of the selected SMEs. These analyses were done using Statistical package for Social Sciences (SPSS).

\section{Results and discussion}

The tables below show the results obtained from the analyses carried out.

Tables 1 to 5 show the cost data of the selected SMEs within the study area. The cost of power supply from PHED and total cost of power supply using private power generating set were enumerated for the 24 months under consideration. The correlation between the costs of using power supply from PHED and power supply from private power generating set for each of the selected SMEs was calculated by using SPSS software application. The results of the analyses are shown on Tables 6 to 10. All the results yielded negative correlation coefficients which suggest a negative impact on the profitability of businesses in the study area. These results agree with the finding of [10] which recorded correlation coefficients of $-0.301,-0.287$ and -0.268 for the three telecommunication base stations in his research. He stated that the negative values confirm that the effect of the power outages in the base stations increased the operating costs for the case study base stations.

Table 6 Correlation of Cost data for SME 1

\begin{tabular}{|l|l|c|c|}
\hline \multicolumn{2}{|c|}{} & SME1PHED & SME1PP \\
\hline \multirow{4}{*}{ SME1PHED } & Pearson Correlation & 1 & $-.716^{* *}$ \\
\cline { 2 - 4 } & Sig. (2-tailed) & & .000 \\
\cline { 2 - 4 } & $\mathrm{N}$ & 24 & 24 \\
\hline \multirow{4}{*}{ SME1PP } & Pearson Correlation & $-.716^{* *}$ & 1 \\
\cline { 2 - 4 } & Sig. (2-tailed) & .000 & \\
\cline { 2 - 4 } & $\mathrm{N}$ & 24 & 24 \\
\hline \multirow{2}{*}{$* *$ *. Correlation is significant at the 0.01 level (2-tailed). } \\
\end{tabular}


Table 7 Correlation of Cost data for SME 2

\begin{tabular}{|l|l|c|c|}
\hline \multicolumn{2}{|c|}{} & SME2PHED & SME2PP \\
\hline \multirow{4}{*}{ SME2PHED } & Pearson Correlation & 1 & -.188 \\
\cline { 2 - 4 } & Sig. (2-tailed) & & .378 \\
\cline { 2 - 4 } & $\mathrm{N}$ & 24 & 24 \\
\hline \multirow{3}{*}{ SME2PP } & Pearson Correlation & -.188 & 1 \\
\cline { 2 - 4 } & Sig. (2-tailed) & .378 & \\
\cline { 2 - 4 } & $\mathrm{N}$ & 24 & 24 \\
\hline
\end{tabular}

Table 8 Correlation of Cost data for SME 3

\begin{tabular}{|c|c|c|c|}
\hline & SME3PHED & SME3PP \\
\hline \multirow[t]{3}{*}{ SME3PHED } & Pearson Correlation & 1 & $-.848^{* *}$ \\
\hline & Sig. (2-tailed) & & .000 \\
\hline & $\mathrm{N}$ & 24 & 24 \\
\hline \multirow{3}{*}{ SME3PP } & Pearson Correlation & $-.848^{* *}$ & 1 \\
\hline & Sig. (2-tailed) & .000 & \\
\hline & $\mathrm{N}$ & 24 & 24 \\
\hline
\end{tabular}

Table 9 Correlation of Cost data for SME 4

\begin{tabular}{|l|l|c|c|}
\hline \multicolumn{2}{|c|}{} & SME4PHED & SME4PP \\
\hline \multirow{3}{*}{ SME4PHED } & Pearson Correlation & 1 & -.273 \\
\cline { 2 - 4 } & Sig. (2-tailed) & & .197 \\
\cline { 2 - 4 } & $\mathrm{N}$ & 24 & 24 \\
\hline \multirow{3}{*}{ SME4PP } & Pearson Correlation & -.273 & 1 \\
\cline { 2 - 4 } & Sig. (2-tailed) & .197 & \\
\cline { 2 - 4 } & $\mathrm{N}$ & 24 & 24 \\
\hline
\end{tabular}

Table 10 Correlation of Cost data for SME 5

\begin{tabular}{|l|l|c|c|}
\hline \multicolumn{2}{|c|}{} & SME5PHED & SME5PP \\
\hline \multirow{4}{*}{ SME5PHED } & Pearson Correlation & 1 & $-.849^{* *}$ \\
\cline { 2 - 4 } & Sig. (2-tailed) & & .000 \\
\cline { 2 - 4 } & $\mathrm{N}$ & 24 & 24 \\
\hline \multirow{4}{*}{ SME5PP } & Pearson Correlation & $-.849^{* *}$ & 1 \\
\cline { 2 - 4 } & Sig. (2-tailed) & .000 & \\
\cline { 2 - 4 } & $\mathrm{N}$ & 24 & 24 \\
\hline
\end{tabular}




\section{Conclusion}

The results from this study show that electrical power outages have significant negative effects on the businesses of small and medium scale enterprises (SMEs) which in turns affect their profitability and sustenance. Generally and as it can be inferred from this study, electrical power outages increase the operational cost of doing business and contribute to a large extent major impediment to the growth and development of SMEs in this country. Majority of the SMEs depend basically on public power supply and private generating set as sources of power supply for their businesses, so with the high frequency of power outages experience in the study area, most of the business owners result to the use of private generating sets to run their businesses in absence of the public power supply so as to keep their businesses running. The overall effect of this is to incur additional operational cost which has negative effect on their profits.

The following possible ways among others have been identified to reduce the power outages in Elelenwo community based on the causes attributable to the faults.

- $\quad$ Equipment failures

There should be regular maintenance of the line materials. Bad disc, wooden cross-arms and isolators should be changed. Maintenance crew comprises of PC \& M engineers and electrical fitters should carry out maintenance at least once a month and faulty equipment identified should be replaced and not by-passed. Old wires should be replaced with new ones to avoid wire cut due to over loading and aging.

- Weather/Environmental conditions Vegetation should be cleared from lines as soon as possible. Sub-stations should be weeded and maintained regularly at least once a month. Wooden poles should be changed to the recommended concrete poles and wooden cross-arms should be replaced with the ones made of fibre to be able to withstand some levels of rain, wind and breeze.

- Human errors The PC \& M engineers and electrical fitters should adhere to correct use of materials and settings according to the Original Equipment Manufacturers (OEM) specifications and Standard Operating Procedures (SOPs) should be followed

- $\quad$ Theft and Burglary Distribution system sub-stations should be adequately protected to prevent theft and burglary of essential and expensive materials such as armoured cables and fuse cartridges

- Accident Distribution system lines and equipment should be guarded against vehicular accident by maintaining right of way for power distribution system facilities

\section{Compliance with ethical standards}

\section{Acknowledgments}

The authors acknowledge the managements of De-Vine Hotels, Zion Technology \& Innovation Centre, ID Best Barbing Salon, DOMIT Electricals and REMZ Laundry Services, all in Elelenwo Community, Port Harcourt, Rivers State.

\section{Disclosure of conflict of interest}

The authors whose names are Frederick Itunu Olajide and A.O. Ibe certify that they have no affiliations with or involvement in any organization or entity with any financial interest or non-financial interest in the subject matter or materials discussed in this manuscript.

\section{References}

[1] Uchendu O. A. Economic cost of electricity outages: Evidence from a sample study of Industrial and Commercial Firms in the Lagos Area of Nigeria. CBN Economic \& Financial Review. 1993; 31(3): 183-195.

[2] Adenikinju A. Analysis of the Cost of Infrastructure Failure in a Developing Economy. The Case of the Electricity Sector in Nigeria. AERC Research Paper 148, African Economic Research Consortium Nairobi. 2005.

[3] Olayemi S. O. Electricity crisis and manufacturing productivity in Nigeria (1980-2008). Developing country studies, ISSN2225-0565 (online). 2012; 2(4): 16-21. 
[4] Subair K, and Oke D. M. Privatization and Trends of Aggregate Consumption of Electricity in Nigeria: An Empirical Analysis. African Journal of Accounting, Economics, Finance and Banking Research. 2008; 3(3): 18-27.

[5] Eniola A. A, and Ektebang, H. SME firms' performance in Nigeria: Competitive advantage and its impact. 2014.

[6] Okafor L. I, Onifade T. A, and Ogbechi A. D. Analytical Review of small and medium scale enterprises in Nigeria. (International Journal of small Business and Entrepreneurship Research (Ijser). 2018; 6(2).

[7] The Guardian, 06 April, 2021

[8] Frimpong, C.Y. SMEs as an Engine of Social and Economic Growth in Africa. (Modern Ghana Featured Article, 29 July, 2013). https://www.modernghana.com/news/478225/1/smes-as-an-engine-of-social-and-economicdevelopme.html

[9] Modi A, and Adamu J. Impact of power (electricity) supply on the performance of small and medium scale enterprises in Adamawa State: Case Study of Mubi North Local Government Area International Journal of Humanities and Social Science Research (IJHSR). 2016; 2(12):04-13.

[10] Ideh, A.E. "Assessing effects of power outages on commercial consumers: A case study of Port Harcourt garden city central area". A Dissertation submitted to the school of graduate studies, University of Port Harcourt, Port Harcourt, Nigeria. 2015 